\title{
Air Transport Demand Forecast to Making the Regional Aviation Sustainable in Northeast of Brazil
}

\author{
Aldrin Pietro de Azevedo Sampaio ${ }^{1}$, Maurício Oliveira de Andrade $^{1}$, Viviane Adriano Falcão ${ }^{1}$, Maria Cecília de \\ Farias Domingos $^{2} \&$ Andersonn Magalhães de Oliveira ${ }^{1}$ \\ ${ }^{1}$ Department of Civil and Environmental Engineering, Center of Technologies and Geosciences, Federal \\ University of Pernambuco, Recife - Pernambuco, Brazil \\ ${ }^{2}$ Air Transport and Airport Infrastructure Postgraduate Program, Aeronautics Institute of Technology, São José \\ dos Campos-São Paulo, Brazil \\ Correspondence: Viviane Adriano Falcão Department of Civil and Environmental Engineering, Center of \\ Technologies and Geosciences, Federal University of Pernambuco, UFPE, Avenida da Engenharia, s/n - Cidade \\ Universitária, 50670-420, Recife - Pernambuco, Brazil. Tel: 55-819-9141-6085. E-mail: viviane.afalcao@ufpe.br
}

Received: September 26, 2021

Accepted: November 11, 2021

Online Published: November 12, 2021

doi:10.5539/jsd.v14n6p69

URL: https://doi.org/10.5539/jsd.v14n6p69

\begin{abstract}
Both researchers and Government Agencies see aviation as an important driver for regional development and national integration. Thus, this sector has been a matter of concern for the government who has ways to stimulate the aero activity. The Regional Aviation Development Program (PDAR) has been currently under development implemented in Brazil. This program foresees public investments in airport infrastructure and operational subsidies for airlines to enhance the sector operation and increase the number of locations served by regional aviation. This paper presents a model for estimating passenger demand potential through multiple linear regression to cover the great majority of the federative units (states) of Pernambuco, Paraíba, Rio Grande do Norte, Ceará, and Piauí in the northeast of Brazil. Subsequently, localities are suggested to optimize the resources of the PDAR, and we concluded that it is likely that there are regions with higher demand potential than some regions, which are already served by the airlines. Hence, we assumed that by strategically directing investments to specific localities, companies operate without subsidies, which in turn can be directed to airlines used to integrate the country. This making regional aviation more sustainable leading development to isolated localities, and thus efficiently contributing to reducing the Brazilian social inequality.
\end{abstract}

Keywords: regional aviation, demand potential, airport catchment area, air transport, sustainability

\section{Introduction}

The impact of regular regional flights on economic development is widely studied in the literature (Postorino; Praticò, 2012; Adler et al., 2013; Freire; Silva, 2017; Fageda et al., 2018; Das et al., 2020; Merket; Beck, 2020; $\mathrm{Wu}$ et al., 2020). Air connectivity to medium-sized isolated cities can ensure more accessibility and evolution of the local market. For Das et al. (2020), the volume of passengers using air transport has grown due to factors such as the addition of new routes, lower fares, and higher flight frequencies.

Deregulation in the aviation industry has led to greater competition among airports in the world (Das et al., 2020). In Brazil, regulatory flexibility began with a delay of more than 20 years when compared to more developed countries, such as the United States, France, England and Germany (Ruiz et al., 2014). This process caused the massification of air transport in the nations previously mentioned in the mid-1970s, but it only happened in Brazil from the beginning of the 2000s. Since then, the sector has adopted a strategy of popularizing air transport, offering it as a product within reach of users with lower income, instead of offering a product to high-income consumers or executives. Regulatory flexibility has apparently brought benefits to consumers. This finding can be seen in the historical series for the period from 2000 to 2015, which was made available by the National Civil Aviation Agency (ANAC) (2016), as it is the sector's regulatory body, regarding the number of passengers transported, flights performed, aircraft occupancy rate and fare prices. The growth in the annual number of paying passengers, with more intensity from 2003 to 2012, presented average annual rates around 13\%. Between 2012 and 2015, this growth decreased slightly, reaching annual rates of $2.75 \%$, albeit still positive. This increase in the scale of the competing national air market allowed a reduction in average fares (ANAC, 2016). Although the reduction in ticket 
prices embraced a class that had been previously excluded from the civil aviation market due to their economic conditions, the number of municipalities regularly served by airlines was reduced.

According to BNDES (2002), the number of Brazilian municipalities regularly served by civil aviation reached its peak in 1950, when 358 airports operated in the country. With the regulation flexibility in the sector, airlines directed their aircraft to markets with a higher demographic and economic density, expanding flights supply, reducing ticket prices, and improving the occupancy rate of their aircraft. In summary, the demand for air transport increased. However, the number of airports served by airlines decreased, as the lack of subsidies concentrated the service to profitable routes and airports with efficient infrastructure, which has affected the regional market (Freire; Silva, 2017).

This situation associated with the sector competition with the road mode and the lack of subside to the regional market can be considered as one of the factors that can explain the fluctuations in the market and the fact that in June 2018, solely 119 Brazilian airports operated at least 52 scheduled flights in the year (ANAC, 2018). The selection of more profitable routes with higher demands by companies has brought relative isolation by scheduled air transport services from several regions in Brazil. In this context, this scenario has caused difficulties in the displacement of people and freights, thus preventing the social and economic development of more isolated locations.

Unlike several large countries, which are generally served by an extensive railway network, Brazil has its transport structure based on the road mode. Nevertheless, the current Brazilian highways are neither sufficient nor efficient to make the country integrate and develop appropriately. We identified the incentive to the regular operation of air transport to interconnect the isolated regions with the national and international air network of Brazil as an immediate solution for national integration. The service by a regular flight route can make the difference between territorial isolation and the insertion of the municipality and region of influence of the airport in a route to economic development, promoting the generation of jobs and stimulating the countryside markets and competition in the air sector (Turolla et al., 2011). Despite the existence of locations with strong tourist appeal and a greater economic growth than Brazil in recent years, the Northeast region of the country has not reaped benefits in terms of the growth of its regional aviation, perhaps due to a lack of planning or investments in infrastructure in the most viable locations.

Regarding the Brazilian case, it is essential to identify markets that reveal a potential demand consistent with the feasibility of introducing a scheduled air service, without impacting the regional markets which are currently in operation. In this way, it would be possible to direct investments to locations likely to carry out surplus operations, thus saving resources that are essential for more remote and poorer regions where the operation is naturally deficient. Government support for regional aviation and connections to less densely populated cities occurs in several countries (Das et al., 2020). The presence of isolated and distant areas from large economic centers are factors that lead policymakers to provide subsidies for air transportation, on the other hand, the improvement in accessibility would be unviable (Fageda et al., 2018). For example, essential services such as hospital treatment and education are more deficient in remote areas and underserved regions, which make their population dependent on regional aviation to connect them to more developed cities (Wu et al., 2020).

In this context, the general objective of this article is to propose an econometric model based on demand data from regional cities served by regular air transport. The model allows to estimate potential air transport market demands to cities or regions which have not been operated yet by the service in the Northeast region of Brazil.

\section{Regional Aviation Markets and Demands}

For a large country, regional aviation is extremely important. In Brazil, this segment still has low relevance when compared to the nation's economic potential. Regional aviation allows access to remote areas (Adler et al., 2013), enhances competitiveness with other modes, and affects the cost of production and transportation of various goods and services, leveraging the national economy (Turolla et al., 2011). In addition, it can favor tourism, since remote regions may contain preserved natural resources, which is an attractive feature for tourists looking for some experience in the periphery (Wu et al., 2020). Accessibility is an important factor in economic analysis as it identifies how people manage to reach a location using the existing transport network (Redondi et al., 2013). The economy can be positively driven by improving accessibility, since the costs to reach a certain place are reduced, allowing the consumer to enjoy more of the local market.

According to Bettini (2007), regional aviation is very susceptible to costs regarding the number of passengers transported per flight and distance flown. It causes a huge disadvantage in terms of commercial aviation carried out on high-density lines, regarding the apportionment of operational and administrative costs per passenger and per distance flown. This situation leads regional aviation to be considered an unfavorable economic activity, 
particularly concerning the management of its operational and administrative costs. It is necessary to insert each airport under study in the context of feasible national and continental routes (Redondi et al., 2013), according to the terminal's infrastructure and accessibility to assess the impact of regional aviation on the economy in the region.

Caves et al. (1984) and Fageda et al. (2018) indicate that regional air transport companies are less likely to benefit from economies of scale and greater in economies of density. It means that their average costs are decreasing not according to the inclusion of new flights, but when more passengers travel on a flight route or to more distant locations. Thus, the high average costs of regional airlines do not come from their smaller size or fleet, but from their lower density of operations. In this context, regional airlines tend to increasingly incorporate aircraft with greater passenger and cargo capacity to reduce their average cost per seat or operate longer routes to decrease the average cost per kilometer.

In this context, through the density economy, the sector's regulatory flexibility promotes airlines to achieve economic efficiency, reducing their costs by increasing the distance traveled and the number of passengers transported. In summary, it is concluded that airline costs are reduced when more passengers are transported over a greater distance. Turolla et al. (2011) affirm that since regional air transportation tends to have less dense flights, density economy is an ideal strategy to the search for increasing the volume of passengers on a fixed flight network.

Regarding elasticity, and justifying the need for regulation in the sector, Oliveira and Salgado (2008) highlight that approximately $70 \%$ of demand in Brazil is represented by passengers interested in business, that is, people who travel on business. This market share is characterized as inelastic at prices and highly elastic to flight schedules, the quality of services and their frequency. In the same study it is observed that about $25 \%$ of the demand is constituted by the tourist activity, which presents a seasonal demand, more sensitive to prices and ticket financing conditions and less sensitive to flight schedules.

Additionally, it is noteworthy that there are countries that develop national transport networks to connect airports in less densely populated cities to a hub, or even to insert a regional hub to decentralize movement in some metropolitan centers (Das et al., 2020). In contrast, in Brazil there are major cities in economic development located in peripheral regions regarding the state capitals, which are relatively disconnected from the regular air transport network.

In recent decades, there has been a significant reduction in the locations served by regular air transport, due to the extinction of tariff or operational subsidies to companies. According to Bettini and Oliveira (2011), the supply of seat-kilometers in medium density markets, requires a minimum demand that generates revenues to cover the fixed and variable costs of the activity, such as aircraft, fuel, employees and aviation fees.

\subsection{Regional Aviation in Brazil}

According to Oliveira and Salgado (2008), regional aviation is usually associated with low-density air connections (few passengers per trip) and short flight stage (short flight distance). For Bettini (2007), the economic aspect that best characterizes regional aviation is the high value of its fixed costs, arisen from low-density operations, which results in a concentrated cost value in the few passengers transported per flight and distance flown.

Regional aviation is subject to few operations since there are locations and communities that are not in favor of consolidating routes (Fageda et al., 2018; Das et al., 2020). This is linked to the inherent costs of aviation, such as fixed aircraft operating and supply costs, which in the presence of poorly developed markets, might be higher (Fageda et al., 2018). In a competitive environment among airlines, regional services are often excluded due to low traffic and low revenue potential (Das et al., 2020).

To improve the regional market, the interdependence among modes can provide an increase in passengers for aviation. According to Merket and Beck (2020), the integration between air and road transport can offer competitive advantages over the most common competitors in the regional market, the private car. The partnership between airlines and public transport operators to provide a full ticket that covers the air ticket and the shuttle service to access the terminal may encourage travelers to abandon their cars and choose public transport options (Merket; Beck, 2020). This promotes more passengers interested in regional aviation, due to the easy access, low cost, and short travel time, which generate business opportunities for airlines (Merket; Beck, 2020).

In contrast, for long journeys, the partnership between airlines and shuttle services may not be feasible to reach the final destination. Paiva and Müller (2014) evaluated the competition between the road and air transport, and stated that the longer the trip, the more advantageous the plane becomes comparing it to the bus. In addition to the distance factor, when the price of both the plane and bus tickets are similar, passengers prefer traveling by air. From an economic point of view, road transport is considered a service of inferior quality when compared to air transport. Therefore, an increase in the average income of the population normally produces a shift in demand 
from road to air mode. However, for short routes, air transport needs to be competitive and have higher cross-price elasticity concerning other means of transportation due to the waiting time at the terminal and possible flight delays and cancellations, which make a choice for air modal vulnerable to price differences (Turolla et al., 2011).

Although transportation system is mostly road-related, airports are essential to provide access to regions far from large capitals in Brazil (Freire; Silva, 2017). Oliveira and Salgado (2008) affirm that in the period from 1998 to 2008 , the decrease in the number of cities served by air transport was more significant than the number of new cities that started services in Brazil. They also state that there is a denser regional network in the South and Southeast regions of the country and there was a reduction of attendance in the pre and post liberalization period of $21 \%$ in cities and micro-regions, and of $7.6 \%$ of the served population. Regarding the Northeast region, object of the present study, the low coverage of the regional air transport network is perceived within the period from 1998 to 2008 , with a reduction of $25 \%$ of the municipalities covered by it and of $8.2 \%$ of the served population (Oliveira; Salgado, 2008).

Fageda et al. (2018) and Wu et al. (2020) state that policymakers are increasingly determined to provide subsidies to air terminals located in remote areas or with low market movements due to the consequent economic development linked to connections between the inland cities and large capitals. Additionally, Merket and Beck (2020) suggest that the authorities should be more concerned with the integration between air transport and public transport to promote accessibility and new commercially viable and attractive flights for consumers.

The Brazilian Federal Government has agreements with states' government to provide co-funding to improve projects and expansion of the capacity of air terminals managed by the states (Fageda et al., 2018). The partnership is linked to the Federal Airport Assistance Program, in which the funds come from taxes paid by concessionaires that manage privatized airports and from the general budget (Fageda et al., 2018).

In Brazil, the Regional Aviation Development Program (PDAR) was created by the Law 13.097/2015, with the premise to ensure that $96 \%$ of the population was at least $100 \mathrm{~km}$ away from any airport with regular airline operations. As regional aviation serves less dense locations, one of its main bottlenecks is the dilution of fixed and variable costs among passengers, especially in regions with lower income, which may cause fares to present higher values. To alleviate this problem, the Law above mentioned authorizes the federal government to grant an economic subsidy to services offered by regional airports, such as airport and air navigation fares. In addition, the government is also authorized to subsidize part of the operating flight costs to regional routes.

The study of possible airports with the potential to receive financing for regular aviation is essential for the Program to be efficient and ensure that public investments will not be wasted in terminals that do not provide the expected development for the region (Freire; Silva, 2017). Freire and Silva (2017) used the Moran's I statistic (quadrant) method to identify Brazilian regional airports with the potential to receive regular aviation services and that should have priority in public investments. They used the number of airports not regularly serviced by airlines until 2015 in Brazil and the number of interstate bus trips generated due to competition between modes in the country. It was identified theoretical potential airports for regular airline service based on the correlation between the result of the method and the survey carried out with airlines to analyze the desire to operate at one of the airports on the list. It is clear that the knowledge of the locations where airline service is viable is essential for planning and prioritizing airports in terms of investment in infrastructure.

\subsection{Regional Airport Catchment Area and Demand Forecast}

For Augustyniak and Olipra (2014), the area of influence of an airport depends on the passenger's profile. They describe that travelers on business tend to value their time more than passengers on leisure. Postorino (2011) explains in his study that the area of influence of an airport depends on many factors, such as: geographical position, mobility and accessibility, socioeconomic characteristics of potential users and the existence of competing airports. Augustyniak and Olipra (2014), in their study on Poland's regional airports, noted that the catchment area of passengers increases when there are few airports competing for air market in the region. This scenario generally occurs in areas of lower population density, where airports remain attractive to users who are more than two hours away from them.

There are several definitions in the literature on airport catchment areas, in which the geographic or demand aspects are considered. Postorino (2010) says that from a geographical point of view, the catchment area can be defined as the area that contains all potential users and passengers at a given airport. From the perspective of demand, the catchment area is defined as the number of passengers using a given airport, where the origins of these passengers can be identified in a study area.

Lieshout (2012) considers that the area of influence of an airport is the area that surrounds it, from where its 
passengers are attracted. The size of the catchment area, as well as its market share, depends on several decisive factors for passengers to choose a given airport, such as accessibility and level of service offered by the airport in terms of fares and frequencies, in comparison with other competing terminals. He adds that with the establishment of more airports, passengers have more options. This means that the catchment areas of airports are increasingly overlapping. Therefore, the areas of influence are not static and can evolve, depending on changes in airport service supply.

Postorino (2010) presents, in one of his studies on air transport demand modeling for regional airports, that the demand forecast has great relevance for the planning of a transport system. For a regional airport, demand forecasts have a significant influence on the future operation of a terminal, as well as on the development of the airport master plans. Notwithstanding the method to evaluate the demand, Postorino (2010) says that the knowledge of the airport's catchment area is essential since it allows covering the expected demand for the airport and facilitates the understanding of its potential development.

Sivrikaya and Tunç (2013) presented a methodology to estimate the demand for domestic air transport in Turkey, aiming to predict the movement of specific existing air routes and new ones that were not yet operated by airlines. This study was based on methodologies extracted from 15 (fifteen) works related to the theme and considered relevant by the authors. The variables used in their analysis were extracted from the articles, and the most relevant ones were population, GDP, distance, travel time, air fare, GDP per capita, frequency of service, consumer price indices, the volume of imports, employment, costs, exchange rate, expenses, and fuel price.

Rochel (2000) states that air demand is determined by economic, operational and service quality factors. Regarding economic aspects, demand is influenced by two fundamental variables: the population's income and ticket prices (Rochel, 2000). Additionally, the variation in income influences demand more than the variation in ticket prices, that is, the income elasticity is higher than the price elasticity (Rochel, 2000). In this context, as a proxy variable for income, the GNP (Gross National Product) was used in the study. Structural factors as population, travel distances, alternative modes of transport available, and the connectivity of the airport were used to assess the demand.

In a behavioral study for the passenger decision to use air transport, one of the conclusions of the study by Hess (2010) was that the time of access to the airport plays an important role in the selection process since passengers tend to prefer airports closer to the initial point. Therefore, the attractiveness of peripheral airports depends on good access connections, unless there are other relative factors such as low airfares. It is noteworthy that solely low-cost carriers can feasibly attract passengers to distant airports, which are not served by convenient and frequent services. The importance of assessing the behavioral issue of passengers is evident, especially in an environment with a finite possibility of choices.

Augustyniak and Olipra (2014) and Civil Aviation Authority (2011) studied the airports in Poland and London respectively and presented the catchment areas of the market of each airport for regional aviation within one or two hours of road trips, which is equivalent to $110 \mathrm{~km}$ of an average radius.

For an application to the Brazilian market, we used a pattern that is relatively similar to the case of Poland or a country with municipalities whose accesses by road do not exceed the travel time of two hours. The importance of the extension of the catchment area is highlighted by Hess (2010) while concluding that the access time is crucial to the choice of an airport, in which it is related to adequate conditions of land access.

\section{Methodology}

The proposed methodology of this article aims to develop an econometric model by regression analysis to estimate the potential demand for regional air transport in pre-selected unattended areas of states in the Northeast region of Brazil. The states are Pernambuco, Paraíba, Rio Grande do Norte, Ceará, and Piauí, and they were chosen based on data from a set of regional airports that operate scheduled flights in Brazil, associated with the microeconomic theory of demand.

Figure 1 shows the airports in regular operation with catchment area (considered $100 \mathrm{~km}$ ) in the study area in 2015 . We can see that there was a large unattended area in the region with an embraced distribution of level of services on the coast, in contrast to many voids in the inland. In Figure 1, the terminals where new regular flights were established between the years 2016 and 2018 (Mossoró - RN, Aracati - CE, and Jijoca de Jericoacoara - CE) are inserted. The potential demands for this sample are estimated to demonstrate that catchment's area with access times to the airport within two hours by road can cover practically the entire territory, which implies the feasibility of the PDAR. 


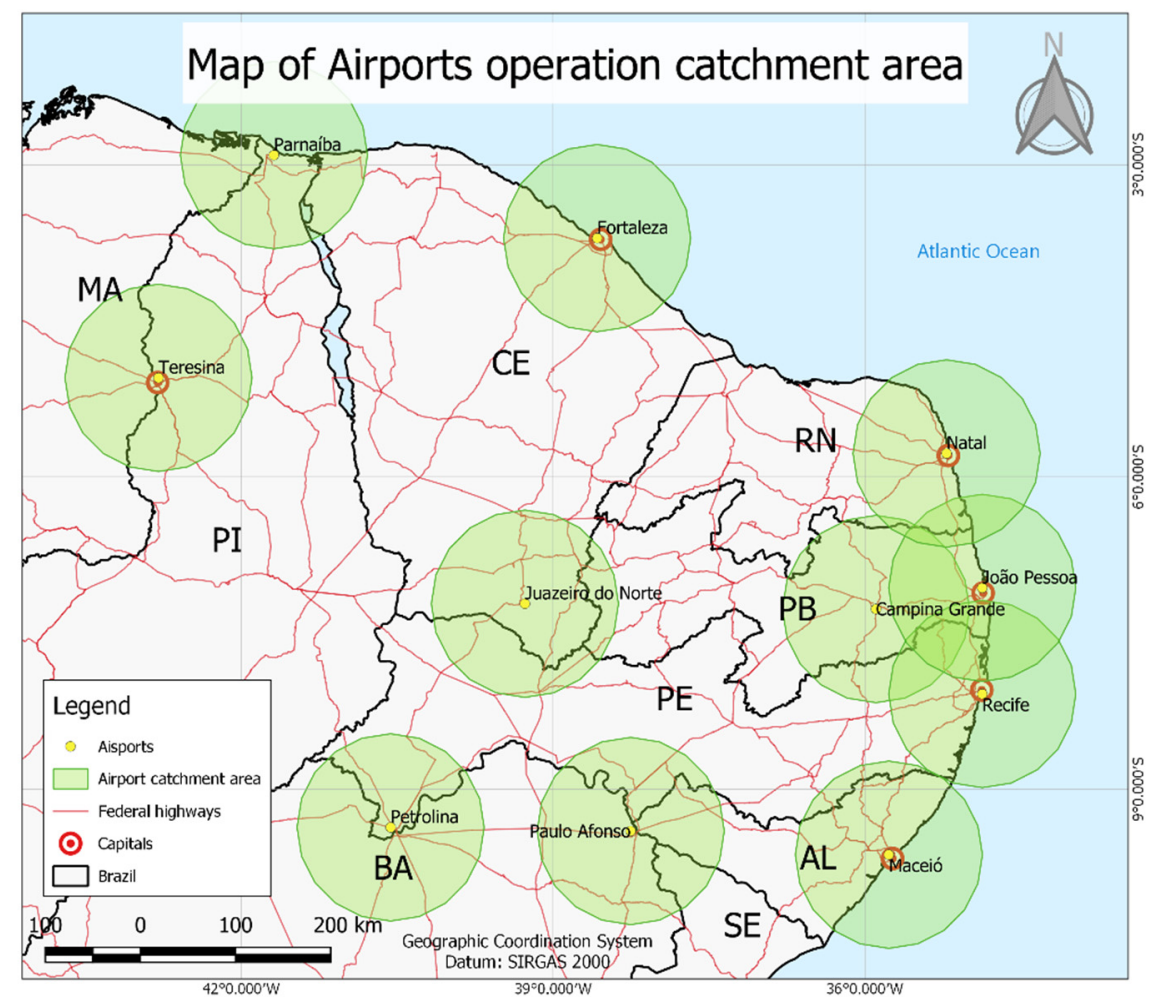

Figure 1. Airports in operation in the Northeast Region in 2015

Source: Authors with information from ANAC (2016).

\subsection{Application of an Econometric Model to the Regional Aviation Market in Brazil}

Econometric models are widely used in demand studies (Karlaftis et al., 1996; Tsekeris, 2009; Marazzo et al., 2010; Kopsch, 2010; Falcão, 2013; Valdes, 2015; Wadud, 2015; Hakim; Merkert, 2016; Hakim; Merkert, 2019) to understand the importance of theoretical and experimental factors, as well as to forecast them within a certain margin of error and confidence interval. The demand forecast is the result of the relationship of independent variables, obtained through mathematical and statistical models. The methodologies used to apply econometrics are varied and depend on the availability of data and the strategy defined by the researcher.

Initially, for the assembly of a model that explains the demand for a product or service, the economic literature identifies the classic variables of the microeconomic theory. It is important to note that Tolcha et al. (2020) noticed causality between air demand and economic development, hence the importance of including socio-economic variables. Regarding transport demand, the consulted literature suggests as influential variables: average airfare and yield, users' income, GDP of the region served, number of employments, distances between terminals and the city centers, quality of service, and fares of the competitor modal such as road transport. In this context, the catchment area of each airport in the sample is demarcated within the criteria of road travel time to the terminal of a maximum of two hours. Thirty-eight (38) regional airports were tested, as listed in Table 1 including ICAO (International Civil Aviation Organization) code from each airport. 
Table 1. Airports chosen for econometric modeling

\begin{tabular}{lccccc}
\hline ICAO & Airports & ICAO & Airports & ICAO & Airports \\
\hline SBUF & Paulo Afonso - BA & SBJU & Juazeiro do Norte - CE & SBPL & Petrolina - PE \\
SWLC & Rio Verde - GO & SBGV & Governador Valadares - MG & SBCA & Cascavel - PR \\
SBDB & Bonito - MS & SBAU & Araçatuba - SP & SWSI & Sinop - MT \\
SBCR & Corumbá - MS & SBKG & Campina Grande - PB & SBQV & Vitória da Conquista - BA \\
SBJI & Ji- Paraná - RO & SNBR & Barreiras - BA & SBMA & Marabá - PA \\
SBSM & Santa Maria - RS & SBZM & Juiz de Fora - MG & SBCH & Chapecó - SC \\
SBPK & Pelotas - RS & SBIP & Ipatinga - MG & SBJV & Joinville - SC \\
SSKW & Cacoal - RO & SBBU & Bauru - SP & SBUL & Uberlândia - MG \\
SBML & Marília - SP & SBCN & Caldas Novas - GO & SBIL & Ilhéus - BA \\
SBUR & Uberaba - MG & SBPF & Passo Fundo - RS & SBSR & São José do Rio Preto - SP \\
SBRD & Rondonópolis - MT & SBIZ & Imperatriz - MA & SBMG & Maringá - PR \\
SBCM & Criciúma - SC & SBCX & Caxias do Sul - RS & SBLO & Londrina - PR \\
SWGN & Araguaína - TO & SBMK & Montes Claros - MG & & \\
\hline
\end{tabular}

Source: ANAC (2016).

Furthermore, a set of variables were chosen to evaluate the model. The criterion to determine the factors is associated to the data available for all 1,009 municipalities (18\% of the municipalities in the country) that fulfill the catchment areas for regional airports in the sample. Figure 2 represents the annual demand of regional airports considered for the estimation of the econometric model that will serve as a basis for the forecasting model.

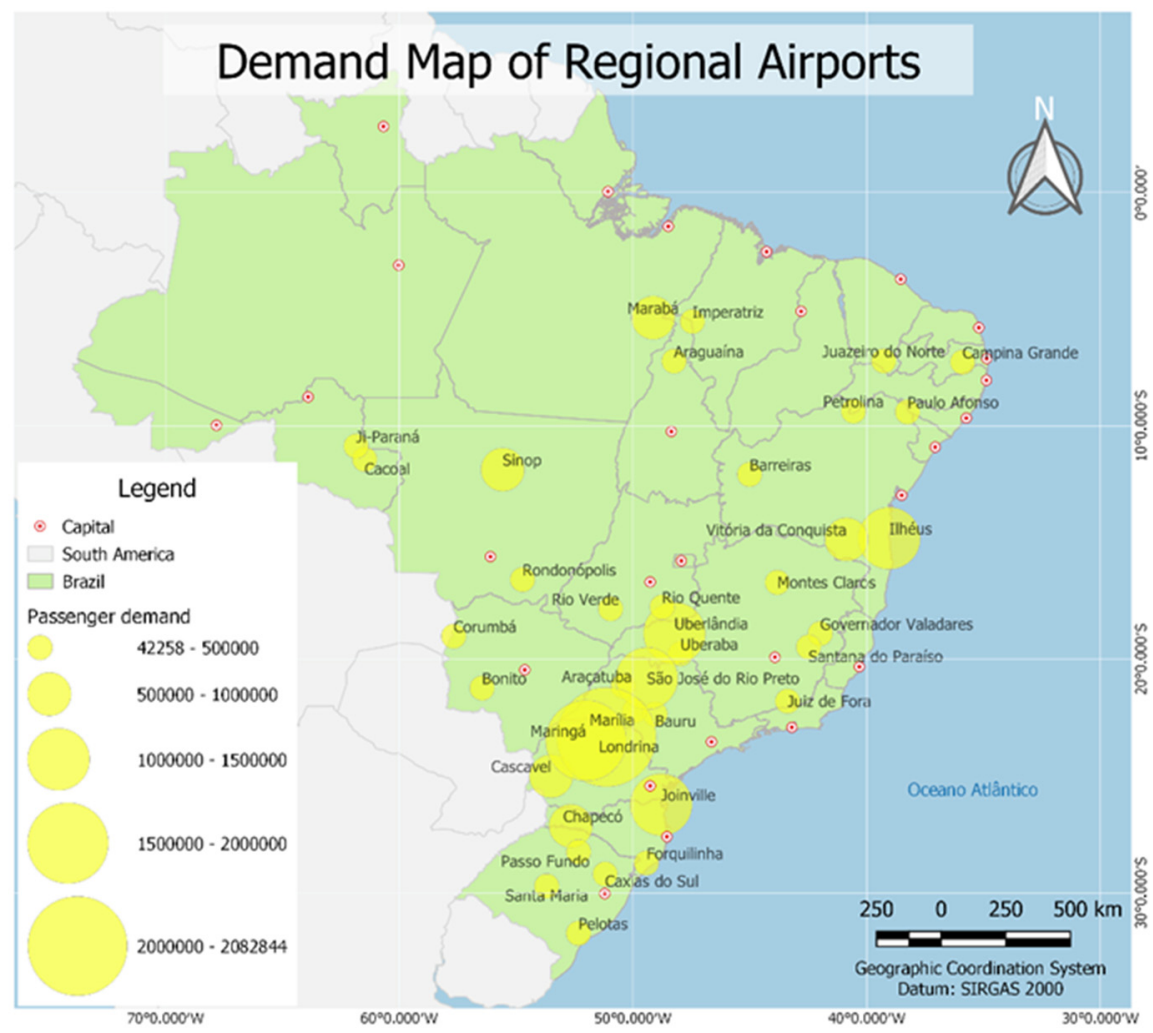

Figure 2. Demand for regional airports used in the modeling

Source: Authors with information from ANAC (2016). 
The third phase of the methodology is associated with the research of data to assemble and test the models. Regarding the passengers' demands, airfares, average yield, and supply level, the elements were obtained through the data of the National Civil Aviation Agency (ANAC, 2020). Socio-economic data on population, municipal GDP, and average income were achieved from the Brazilian Institute of Geography and Statistics (IBGE, 2016). As for the number of employments and average wages, the data were available on the CAGED of the Ministry of Labor and Employment - MTE. In general, the collection of data is not an operation that requires significant effort. Nonetheless, the most challenging operation is to manage a vast majority of data related to a large number of municipalities served directly or indirectly by a set of airports in operation that cover the influence area of the sample.

Depending on the significance of the results obtained based on the microeconomic theory, other variables must be evaluated subsequently. In this context, macroeconomic variables such as regional GDP, GDP per capita, population, and spatial variables are tested in the model to assess impedance values such as proximity between users and airports. Additionally, it is evaluated the impact of the isolation level of air transport markets, as the distance to the alternative airport adjacent.

The aim of this study is presumably to assess the aviation market potential in areas currently not served by this modal following the size and infrastructure of the terminals that are already regularly operating. Thus, it is not evaluated the natural fluctuations in demand in the face of national or regional economic dynamics. The model proposed is part of a cross-section analysis with factors obtained by ANAC (2020) data for the year of 2015.

As this is a study for application to regional air transport markets, the sample was established based on data from passengers handled at regional airports in Brazil with demands between 20,000 and 600,000 passengers embarked and disembarked per year. It is also considered a prerequisite for inclusion in the database, the possibility of access to the airport without restrictions by road throughout a catchment area of travel within two hours. Thus, airports in the Amazon region were not included, where access by road is often severely restricted. Besides, airports with strictly tourist demands such as Foz do Iguaçu - PR, Porto Seguro - BA, and Fernando de Noronha - PE were not included. In this demand spectrum, 33 regional airports operated in Brazil in 2015 (the base year of the study).

The structuring of the econometric model arises from several tests, which results in an appropriate formulation. After verifying the significant variables for the model, we made tests to assess the assumptions of normality of errors, non-multicollinearity, homoscedasticity and non-autocorrelated errors.

Therefore, we represented the application of the model for the regional air transport market demand in Brazil to areas not served in the states of Pernambuco, Paraíba, Rio Grande do Norte, Piauí, and Ceará, thus demonstrating the potential of the regions covered by this demand. As the parameters obtained in the regression present a margin of error of $5 \%$ in a $95 \%$ confidence interval, the demands presented will refer to the predicted averages and their possible minimum and maximum values.

\section{Econometric Modeling}

Based on economic theory and consulted literature (Falcão, 2013; Valdes, 2015; Wadud, 2015; Hakim; Merkert, 2016; Hakim; Merkert, 2019), the main variables for the demand forecast of a product are its price, the consumer income and the cost of related products.

We collected the population, GDP of the region served, GDP per capita and average income through IBGE (2016) data to characterize the consumption capacity of the market. Besides, we obtained spatial data such as average distance to the airport and average distance to the nearest alternative airport to characterize the price of the product, an average airfare for each market was used, based on data from ANAC (2020). The average price of road fares for the same destinations indicated by ANAC was used to describe the related products. Furthermore, a dummy variable was included to differentiate the airports in the South and Southeast regions of Brazil, where there are greater competition and a more consolidated market. It is noteworthy that this variable was used to discern the most and least developed regions of Brazil. The variable named as the "SeSE region" assumes the following values: South and Southeast regions (1) and North, Northeast, and Center-West regions (0). Figure 3 presents the correlation matrix of the variables. The values above 0.8 in module can be considered as variables with a strong correlation. 


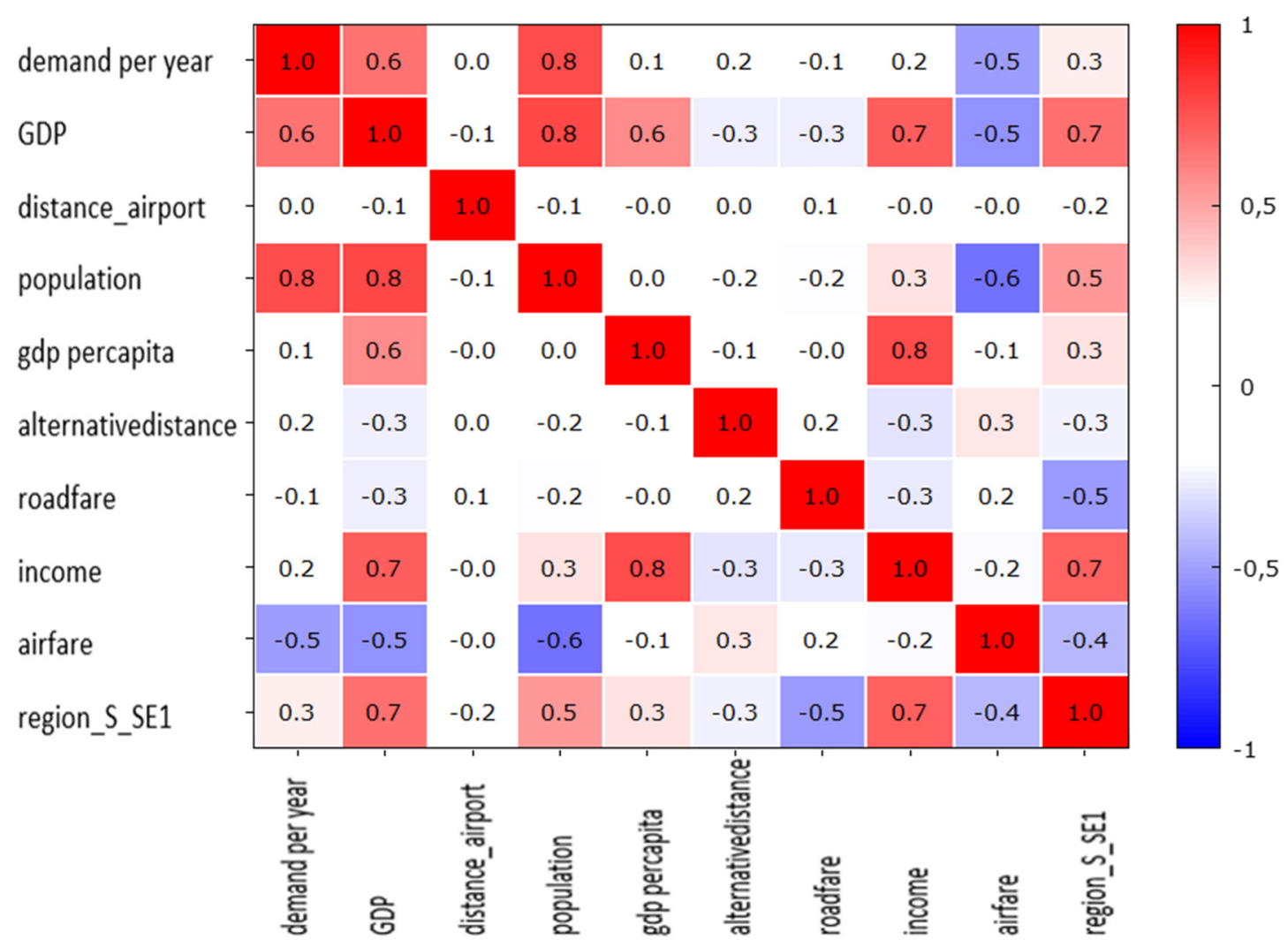

Figure 3. Correlation matrix of the variables used in the modeling

We evaluated distinguished models with particular combinations of variables. Those, which had the best p-value and $\mathrm{R}^{2}$, were chosen as representative models of the demand for the Brazilian regional airports. It is important to note that all models were processed with corrected heteroscedasticity, which resulted in $\mathrm{R}^{2}$ values closer to 1 . Also, while analyzing the behavior of the explanatory variables of the model against the independent variable, we noticed that there is a heterogeneous variation in the demand as it is modified. This relation can be seen in Figure 4, in which the annual demand versus GDP and annual demand versus population are represented.
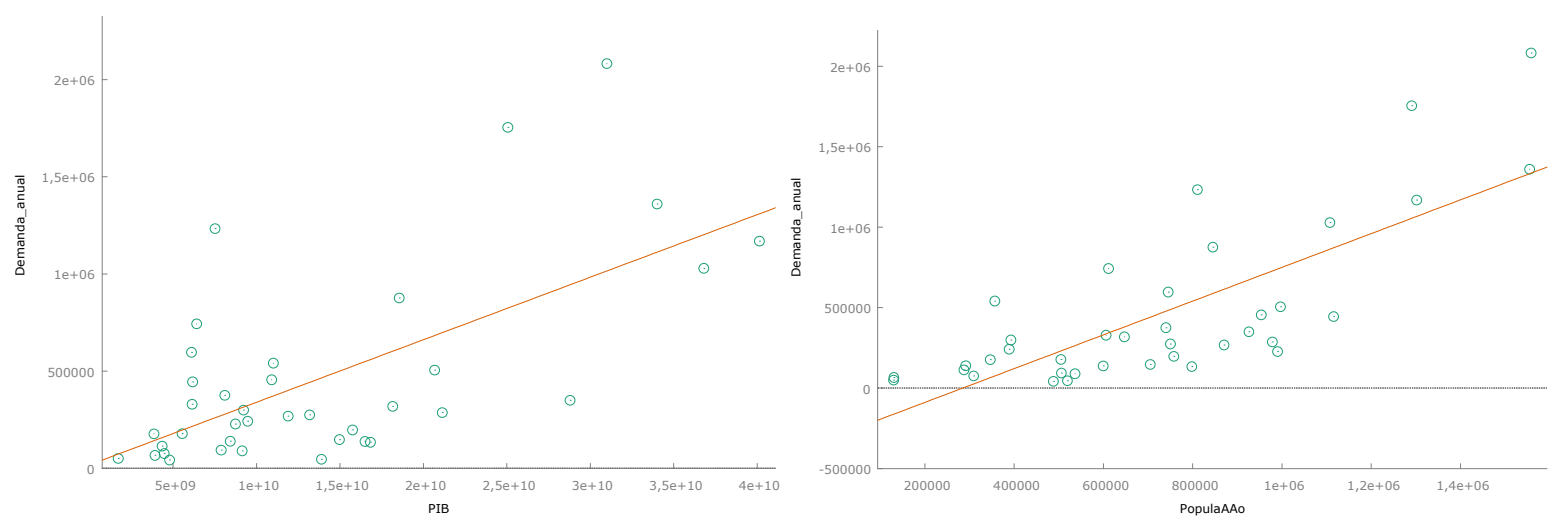

Figure 4. Scatter Plots: Demand x GDP and Demand x Population

Source: Data from ANAC (2020) and IBGE (2016), with authors' calculations.

According to Table 2, the model which showed the best adjustment was the log-lin model, whose dependent variable is logarithmic and the independent ones are linear. The p-values are represented by asterisks, in which the most significant variables are the ones with the highest number of asterisks. Despite the low volume of observations, it is also important to note that the adjusted $\mathrm{R}^{2}$ of the models performed significantly, which is 
important for the final forecast.

Table 2. Demand models for the sample

\begin{tabular}{|c|c|c|c|c|c|c|c|c|c|}
\hline \multirow{2}{*}{$\frac{\text { Model }}{\text { variables }}$} & \multicolumn{3}{|c|}{ lin-lin } & \multicolumn{3}{|c|}{$\log -\operatorname{lin}$} & \multicolumn{3}{|c|}{$\log -\log$} \\
\hline & Coefficient & P-value & & Coefficient & $P$-value & & Coefficient & $P$-value & \\
\hline const & -216124 & 0,417 & & 11,523 & $<0,0001$ & $* * *$ & $-10,7989$ & 0,0456 & $* *$ \\
\hline GDP & 4,99E-06 & 0,4761 & & $3,34 \mathrm{E}-11$ & 0,0049 & $* * *$ & & & \\
\hline Population & 0,859434 & 0,0002 & $* * *$ & $1,45 \mathrm{E}-06$ & $<0,0001$ & $* * *$ & & & \\
\hline AlternativeDistance & 1173,34 & 0,0002 & $* * *$ & 0,00240777 & $<0,0001$ & $* * *$ & & & \\
\hline AirFare & $-602,960$ & 0,0725 & * & $-0,00205067$ & 0,0011 & $* * *$ & & & \\
\hline RoadFare & 195,878 & 0,6775 & & 0,000309913 & 0,8263 & & & & \\
\hline RegionSeSE1 & -223325 & 0,0086 & $* * *$ & $-0,452756$ & 0,0842 & $*$ & $-0,842993$ & 0,008 & $* * *$ \\
\hline 1_GDP & & & & & & & 0,586307 & 0,024 & $* *$ \\
\hline I_Population & & & & & & & 0,966184 & 0,0006 & $* * *$ \\
\hline 1_AlternativeDistance & & & & & & & 0,89306 & $<0,0001$ & $* * *$ \\
\hline 1_AirFare & & & & & & & $-1,30888$ & 0,0003 & $* * *$ \\
\hline I_RoadFare & & & & & & & 0,0894305 & 0,7016 & \\
\hline $\mathbf{R}^{2} \_\mathbf{a}$ & & 92194 & & & 42106 & & & 394756 & \\
\hline
\end{tabular}

ABEAR studies (2015) have already highlighted GDP as a critical proxy variable for consumer income for estimates of air transport demand in Brazil. In contrast, these same studies highlighted the relevance of the tariff in estimating demand, which was not confirmed significant in the present study, as described and justified subsequently.

The variables that represent road transport prices were excluded from the model because they have high p-values, approximating 0.60 . This increase in variance might be due to aggregated data, which do not capture the relative price variations between regions and the pricing strategies of the operating companies. Additionally, it is noteworthy that it is a tariff regulated by the National Land Transport Agency (ANTT). To test the level of isolation of the airport's catchment area concerning the nearest alternative airport, the average distance to this terminal was tested, and it was considered significant. As expected, the variable GDP, population, and distance to an alternative airport showed a positive sign. Thus, it shows that the demand for regional air transport arises when those factors enhance. The dummy variable for classifying airports in the South and Southeast of Brazil presented a low p-value and a negative coefficient, which would not be expected from airports with more consolidated markets. This might be due to the significant airport competition in the South and Southeast regions, as in the case of the Triângulo Mineiro - MG, Uberaba - MG and Uberlândia - MG terminals, which are distants of $120 \mathrm{~km}$ from each other. The market competition provides the possibility for the passenger to choose the airport with the lowest fares, which in general is the one with the highest frequency of flights and with the largest number of operating airlines.

In order to increase the explanatory and predictive adjustment of the model, tests were performed with the most significant model from the previous analysis, the log-lin, and from it some variables were included and removed. This model was chosen because it presented the best $\mathrm{p}$-values and adjusted $\mathrm{R}^{2}$ for the independent variables. Moreover, the forecast graph for $95 \%$ confidence intervals was the most suitable, as shown in Figure 5. 


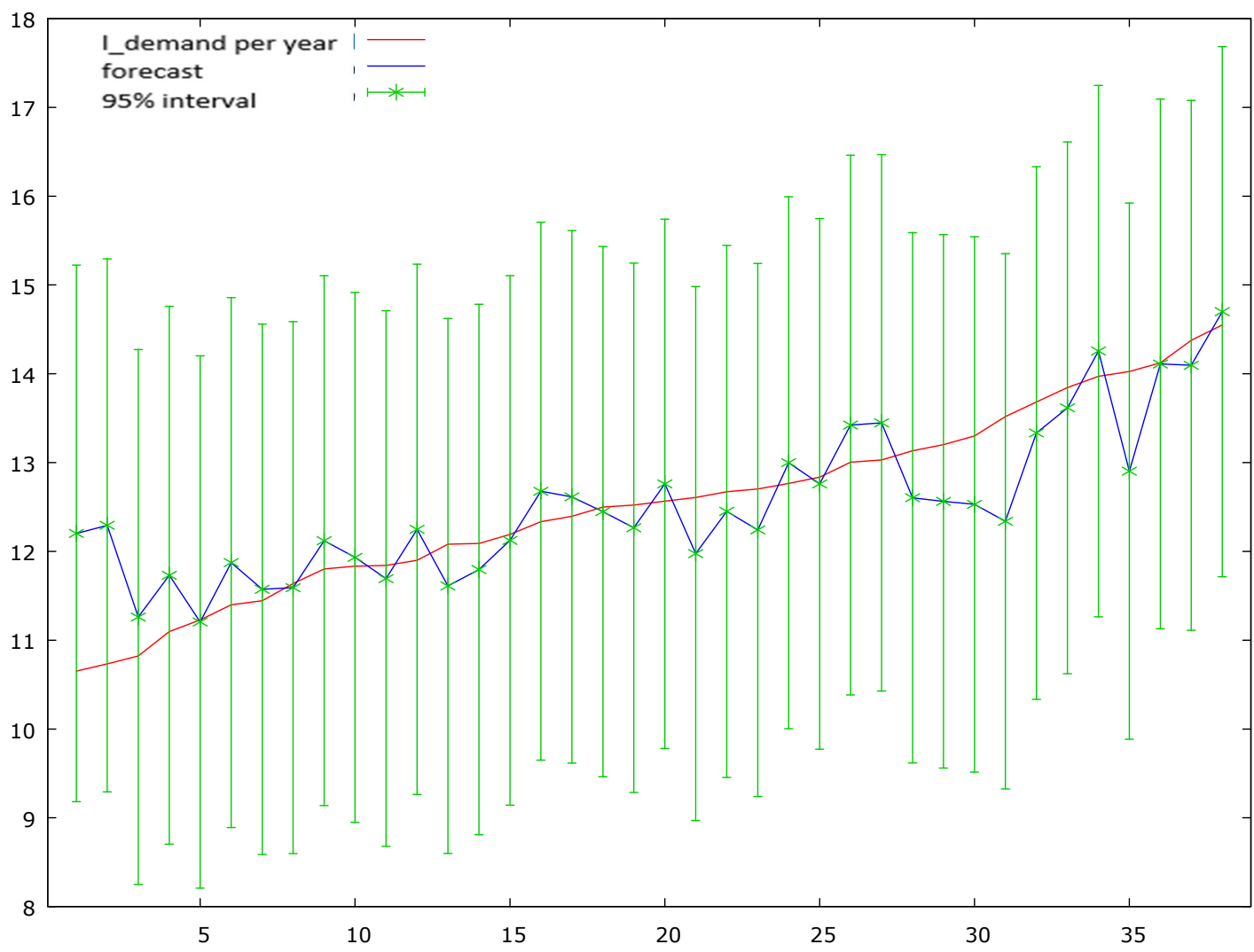

Figure 5. Log-lin model forecast

As previously mentioned, the model chosen as the best accurate in the former analysis was the log-lin one. In this model, which was also assessed with corrected heteroscedasticity, the explanatory variables presented high level of significance. The variables GDP, population and the distance to an alternative airport maintained the positive sign as expected, and airfare and dummy for the South and Southeast region, negative. Likewise, the $\mathrm{R}^{2}$ and the adjusted $\mathrm{R}^{2}$ present significant, in the order of $94 \%$ (Table 3 ).

Table 3. Results of econometric modeling

\begin{tabular}{|c|c|c|c|c|c|}
\hline \multicolumn{6}{|c|}{ Dependent variable: 1_Anual_Demand } \\
\hline & \multicolumn{2}{|c|}{ Coefficient $S$} & \multicolumn{3}{|c|}{ Standard Deviation Stat " $t$ " P-value } \\
\hline Const & \multicolumn{2}{|c|}{11,4756} & 0,452580 & 25,36 & $<0,0001 * * *$ \\
\hline GDP & \multicolumn{2}{|c|}{$3,51585 \mathrm{e}-011$} & $1,03437 \mathrm{e}-011$ & 3,399 & $0,0018 * * *$ \\
\hline Population & \multicolumn{2}{|c|}{$1,43143 \mathrm{e}-06$} & $2,62166 \mathrm{e}-07$ & 5,460 & $<0,0001 * * *$ \\
\hline AlternativeDistance & \multicolumn{2}{|c|}{0,00246860} & 0,000425532 & 5,801 & $<0,0001 * * *$ \\
\hline AirFare & \multicolumn{2}{|c|}{$-0,00199288$} & 0,000563589 & $-3,536$ & $0,0013 * * *$ \\
\hline Region_S_SE1 & \multicolumn{2}{|c|}{$-0,423980$} & 0,200428 & $-2,115$ & $0,0423 * *$ \\
\hline \multicolumn{6}{|c|}{ Statistics based on weighted data: } \\
\hline \multicolumn{2}{|c|}{ Residual sum of squares } & 66,35935 & \multicolumn{2}{|c|}{5 Standard Error } & 1,440045 \\
\hline \multicolumn{2}{|l|}{ R-squared } & 0,949581 & \multicolumn{2}{|c|}{1 R-squared adjusted } & 0,941703 \\
\hline \multicolumn{2}{|l|}{$\mathrm{F}(5,32)$} & 120,5357 & \multicolumn{2}{|c|}{7 P-value(F) } & $8,74 \mathrm{e}-20$ \\
\hline \multicolumn{2}{|l|}{ Likelihood $\log$} & $-64,51213$ & \multicolumn{2}{|c|}{3 Akaike criteriom } & 141,0243 \\
\hline \multicolumn{2}{|l|}{ Schwarz criterion } & 150,8498 & \multicolumn{2}{|c|}{8 Hannan-Quinn criterion } & 144,5201 \\
\hline
\end{tabular}


The verification of possible multicollinearity by the variance inflation factor was performed based on the analysis of the VIF data in Table 4.

Table 4. Statistics of the variance inflation factor (VIF)

\begin{tabular}{cc}
\hline GDP & 3,225 \\
Population & 3,147 \\
AlternativeDistance & 1,134 \\
AirFare & 1,838 \\
Region_S_SE1 & 1,775 \\
\hline
\end{tabular}

The VIF measures how much the variance of the $\beta$ coefficient is inflated by its collinearity. Hence, it verifies the possible multicollinearity by the inflation factor in the variances (Equation 1).

$$
V I F_{J}=\frac{1}{1-R_{j}^{2}}
$$

VIF is generally indicative of multicollinearity problems if VIF $>10$, a situation not achieved in the case under study. As the heteroscedasticity had already been corrected in the estimation of the coefficients, it was considered not to test the model's homoscedasticity.

Besides, Table 5 below shows the $95 \%$ confidence interval for the variables, with the exposure of the critical $t$ and the coefficients.

Table 5. Confidence interval for the coefficients

\begin{tabular}{cccc}
\hline \multicolumn{4}{c}{$\mathrm{t}(32 ; 0,025)=2,037$} \\
\hline Variables & Coefficiente & $95 \%$ Confidence Interval \\
Constant & 11,4756 & 10,5537 & 12,3974 \\
GDP & $3,52 \mathrm{E}-11$ & $1,41 \mathrm{E}-11$ & $5,62 \mathrm{E}-11$ \\
Population & $1,43 \mathrm{E}-06$ & $8,97 \mathrm{E}-07$ & $1,97 \mathrm{E}-06$ \\
AlternativeDistance & 0,0024686 & 0,00160182 & 0,00333538 \\
AirFare & $-0,00199288$ & $-0,00314087$ & $-0,0008449$ \\
RegionSeSE1 & $-0,42398$ & $-0,832237$ & $-0,0157218$ \\
\hline
\end{tabular}

Succeeding the tests and evaluating the theoretical assumptions of the application of multiple regression techniques, the model in Equation 2 is validated for the average coefficients:

$$
\text { lnDemand }=11,48+3,52 * 10^{-11} \mathrm{GDP}+1,43 \times 10^{-6 *} \mathrm{Pop}+0,0025 * \text { AltDist- } 0,002 * \text { AirFare- } 0,42 * \text { Region }+\varepsilon
$$

Applying to this model the average and minimum values of the regression parameters, the potential demands of the markets in the unattended areas is assessed. The airports in the Northeast are represented by the ones located in Ouricuri - PE, Serra Talhada - PE, Garanhuns - PE, Caruaru - PE, Crateús - CE, Sobral - CE, Senador Pompeu - CE, Mossoró - RN, Patos -PB and Picos - PI (Figure 6). 


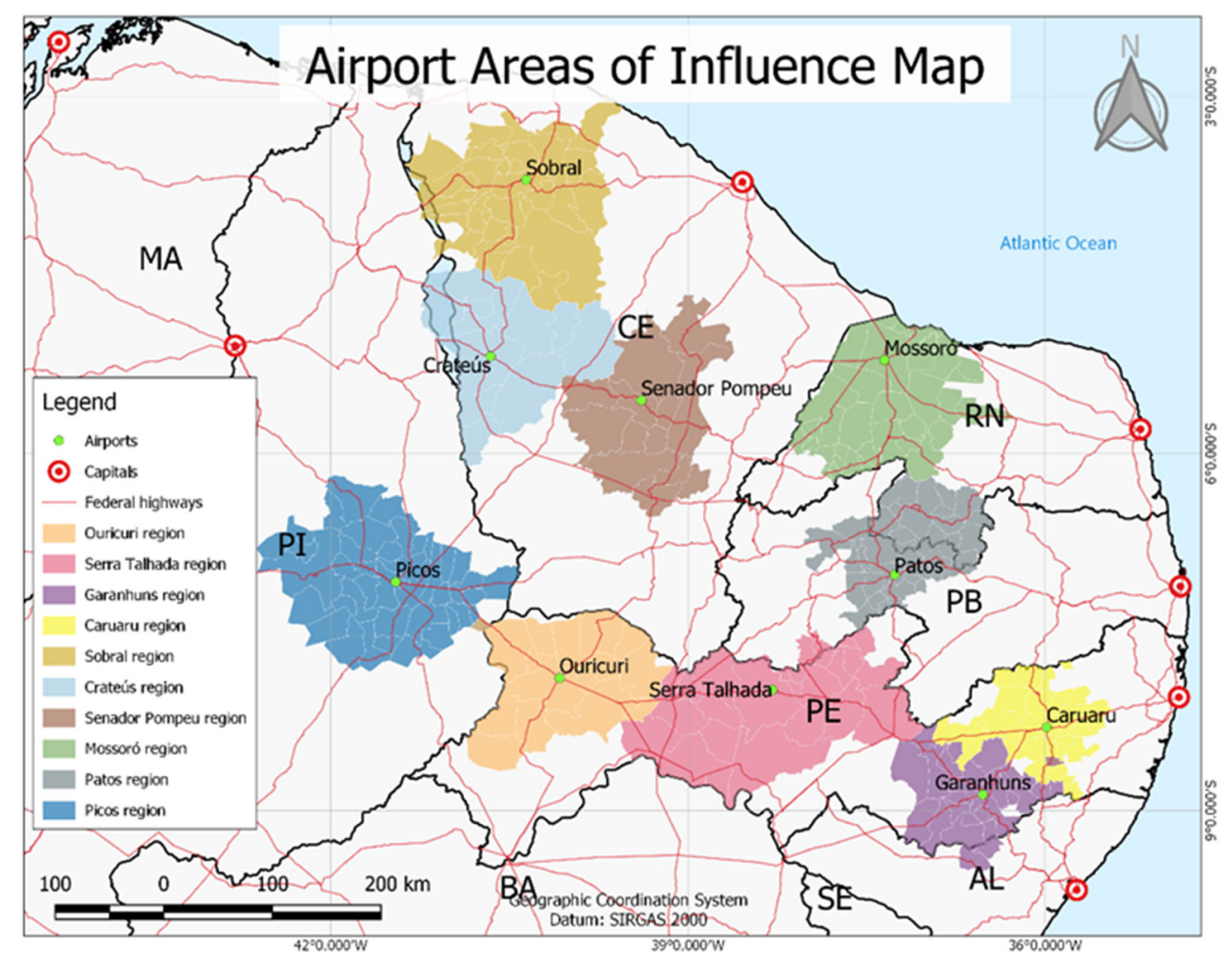

Figure 6. Airports and their areas of influence

Considering the Regional GDP of 2012, the population of the area of influence in 2015, and the airfare of Campina Grande - PB airport, the forecast was established for the markets below (Table 6 and Figure 7), for the average (from Table 4) and minimums values (from Table 5).

Table 6. Demand forecast

\begin{tabular}{lccccc}
\hline \multicolumn{5}{c}{ Average Values } \\
\hline Demand Potential & Serra Talhada & Mossoró & Sobral & Picos & Garanhuns \\
Demand & 158.622 & 254.484 & 349.676 & 137.454 & 247.995 \\
Demand Potential & Caruaru & Ouricuri & Patos & Crateús & Senador Pompeu \\
Demand & 453.353 & 97.740 & 120.445 & 144.396 & 114.568 \\
\hline \multicolumn{5}{c}{ Minimum Values (97,5\% of confidence) } \\
\hline Demand Potential & Serra Talhada & Mossoró & Sobral & Picos & Garanhuns \\
Demand & $19.506,51$ & $25.246,80$ & $31.556,23$ & $18.186,85$ & $25.400,11$ \\
Demand Potential & Caruaru & Ouricuri & Patos & Crateús & Senador Pompeu \\
Demand & $35.380,54$ & $14.518,07$ & $16.508,95$ & $18.772,97$ & $15.946,98$ \\
\hline
\end{tabular}




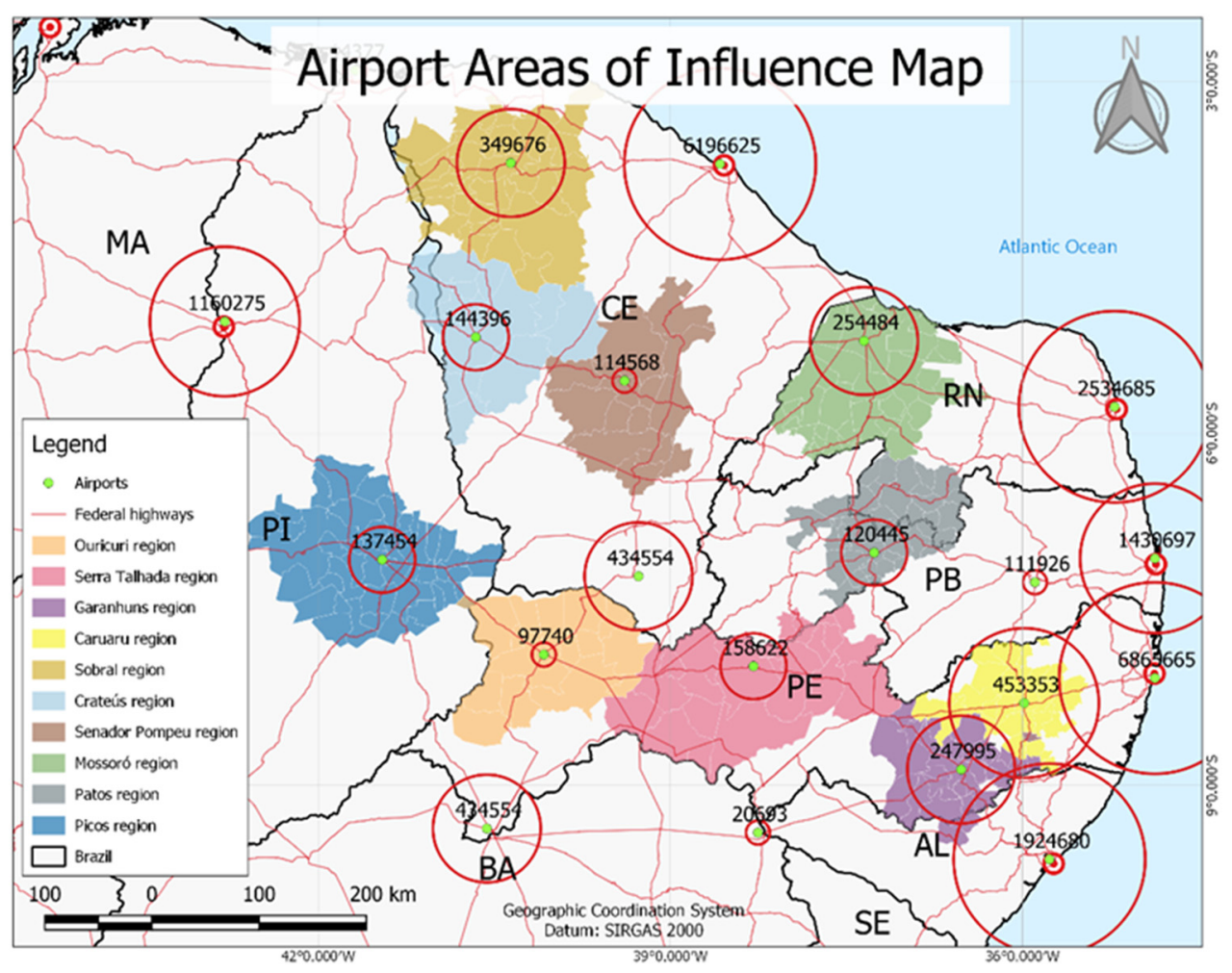

Figure 7. Average demand potential by region for the model sample

\section{Results and Discussion}

Analyzing the airports proposed by the PDAR and the airports encountered by the sample, it is concluded that using a two-hour road trip to the airport as the limit for a catchment area, the number of airports that would require PDAR investments would reduce approximately $50 \%$, as can be seen in Table 7 . 
Table 7. Airports proposed by the PDAR and airports proposed by the study

\begin{tabular}{cc}
\hline Airports proposed by the & $\begin{array}{c}\text { Airports proposed by the } \\
\text { Pample }\end{array}$ \\
\hline Parnaíba - PI & Picos - PI \\
Paulistana - PI & Sobral - CE \\
Picos - PI & Crateús - CE \\
Jijoca de Jericoacoara - CE & Senador Pompeu - CE \\
Itapipoca - CE & Serra Talhada - PE \\
Sobral - CE & Ouricuri - PE \\
Canindé- CE & Caruaru - PE \\
Quixadá - CE & Garanhuns - PE \\
Crateús - CE & Patos - PB \\
Aracati - CE & Mossoró - RN \\
Araripina - PE & \\
Salgueiro - PE & \\
Serra Talhada - PE & \\
Arcoverde - PE & \\
Garanhuns - PE & \\
Caruaru - PE & \\
Afogados da Ingazeira - PE & \\
Monteiro - PB & \\
Patos - PB & \\
Caicó - RN & \\
Mossoró - RN & \\
$\mathbf{2 1}$ & \\
\hline
\end{tabular}

To associate subsidies with new markets without considering the existing ones can contribute to the increase in the public deficit. Since the results intended in this study are to increase the number of passengers transported in regional operations, it is, therefore, evident that the strategy of expanding the catchment areas is essential to reduce the airports to be served and consequently to lower the necessary levels of subsidies.

The demand estimate model was performed using data with corrected heteroscedasticity to obtain the values of average and minimum coefficients. It was possible to obtain the future demand perspective for the airports in the sample, with the demand being in the interval between the minimum and maximum values. Although, it is important to mention that since airports are to be inserted in new markets, initial demand is likely to be closer to the minimum values.

The supply of minimum demands can be associated with the use of the most common aircraft models used in the Brazilian regional market, such as ATR-42 and ATR-72. We can make comparisons between regional airports that currently operate commercial flights, such as the terminals located in Paulo Afonso-BA, Imperatriz-MA, and Barreiras-BA. When simulating ATR-72 flights with an 85\% occupancy rate (60 passengers/trip), with three round trips per week to Serra Talhada - PE, Picos - PI and Cratéus - CE, the number of annual passengers in the order of 19,000 passengers is obtained per year. The result is equivalent to the minimum demand predicted by the model considering $97.5 \%$ of the confidence level. Likewise, when considering the same aircraft model and occupancy rate, and determining four round trips per week to Mossoró - RN and Garanhuns - PE and six round trips per week to Caruaru - PE and Sobral - CE, it is achieved, respectively, 25,000 and 35,000 passengers per year, which represents an approximate movement of the minimum demand foreseen by the model for each terminal, considering the same percentage of a degree of confidence.

For the ATR-42 aircraft, when evaluating the terminals in Ouricuri - PE, Patos - PB and Senador Pompeu - CE, and considering an $85 \%$ occupancy rate (35 passengers/trip) and four round trips per week, demand is also achieved by the minimum value of the model (around 15,000 passengers/year) with a $97.5 \%$ of confidence level. In this context, the possibility of the market being served initially by the minimum demands is ratified, providing heating of the local market and later expansion of the area of influence. 
Also, the model shows that its results might indicate paths to be followed, both by the government and the private sector, to improve airport infrastructure and the operation of air services in regions where its population, GDP and isolation provide a potential demand for scheduled air service. In this context, these regions will use fewer subsidies, which should be reserved for regions where national integration and humanitarian needs can be met exclusively by air.

Regarding the formulating of the model, the study shows that when the distance between the regional airport to be inserted in the network and an alternative airport is considerably high, the chances of success of this new airport is evident, as its demand tends to grow in a linear path. Additionally, it became evident that the definition of the catchment area of an airport in terms of access time for the population served and not only regarding its distance, is what should determine the region covered by the terminal. It indicates that regional accessibility to an airport is an important factor that must be considered in demand studies, thus avoiding overlapping markets, as can be seen in the work of Augustyniak and Olipra (2014).

In the research of the variables applied in the literature on demand for air transport, it was shown that for the study of an econometric model to forecast passenger demand, which is usually based on microeconomic analyzes, the best response to the model is a macroeconomic variable such as GDP. The importance of GDP for the definition of demand estimates can also be seen in the works presented by BNDES (2001), Sivrikaya and Tunç (2013), Falcão (2013), Valdes (2015), Wadud (2015), ABEAR (2015), Hakim and Merkert (2016) and Hakim and Merkert (2019). It is important to note that, Freire and Silva (2017) also considered the airports of Sobral - CE and Caruaru - PE as Brazilian regional airports with a potential to receive regular aviation services and that they should have priority in public investments.

\section{Conclusion}

The prior identification of regions that reveal potential demand that may attract the interest of regional airlines should be the initial step to guide investments in construction, modernization and adaptation of airport infrastructure. Also, knowledge of this potential would guide the selection of the most viable markets, which evidently would require lower levels of subsidy and more economic sustainability.

This article presents an econometric model, based on macroeconomic and geographic data to promote the estimation of potential demand for regions in the Northeast of Brazil. The main intention is to fulfill the areas that seek the provision of air services on a regular area in the federal states of Pernambuco (PE), Paraíba (PB), Rio Grande do Norte (RN), Ceará (CE), and Piauí (PI).

While comparing the potential demand of the proposed unattended locations with the demands of locations where the service is already provided and the markets are consolidated due to uninterruptedly operations throughout decades, it is observed that it is generally smaller, yet superior from many markets in other regions of the country. As an example, the airport in Paulo Afonso - BA can handle about 21 thousand passengers a year, and therefore, it can potentially be surpassed by all ten locations of new operations in the Northeast of the country.

It is important to highlight that the demands estimated by the regression model consider that the new markets are mature, which does not correspond to reality, although this potential can be achieved over the years.

Given the scarcity of studies on the topic, it is suggested for future research to deepen the subject by enhancing the method presented, by performing the regressions using data in a static and dynamic panel. It should be applied data that include several years and variables to increase the samples and to provide a more robust system, verifying the real significance of variables related to income and tariffs and their elasticities. The knowledge of the natural fluctuations in demands can be useful in formulating and redirecting policies and programs that require public resources.

In addition to passenger transportation, another source of funds for the operation of the airport and air transport companies, is cargo transportation, which was not the subject of this work. Thus, the introduction of this important variable is a suggestion for future works.

\section{References}

ABEAR. (2015). Panorama 2015: o setor aéreo em dados e análises, 2015. Retrieved November 20, 2016, from http://www.abear.com.br/uploads/arquivos/dados_e_fatos_arquivos_ptbr/Panorama_2015.PDF

Adler, N., Ülkü, T., \& Yazhemsky, E. (2013). Small regional airport sustainability: Lessons from benchmarking. J. Air Transp. Manag., 33, 22-31. https://doi.org/10.1016/j.jairtraman.2013.06.007

ANAC. (2016). Dados Estatísticos - 2015. Retrieved August 15, 2020, from http://www.anac.gov.br/assuntos/dados-e-estatisticas/dados-estatisticos/dados-estatisticos 
ANAC. (2018). Agência Nacional de Aviação Civil. Anuário do Transporte Aéreo. Retrieved September 8, 2020, from https://www.anac.gov.br/assuntos/dados-e-estatisticas/mercado-de-transporte-aereo/anuario-dotransporte-aereo/anuario-do-transporte-aereo

ANAC. (2020). Consulta Interativa - Indicadores do Mercado de Transporte Aéreo. Retrieved September 12, 2020, from http://www.anac.gov.br/assuntos/dados-e-estatisticas/mercado-detransporte-aereo/consultainterativa

Augustyniak, W., \& Olipra, Ł. (2014). The potential catchment area of Polish regional airports. Journal of International Studies, London, 7(3), 144-154.

Bettini, H. F. A. J. (2007). Um Retrato da Aviação Regional no Brasil. Revista de Literatura dos Transportes, v. 1, p. 46-65.

Bettini, H. F. A. J., \& Oliveira, A. V. M. (2011). Transporte aéreo regional: entre economias de densidade e custos de transação. Journal of Transport Literature, 5(4), 171-187.

BNDES. (2001). Informe infraestrutura, aspectos de competitividade do setor aéreo - modal Aéreo II. Rio de Janeiro.

BNDES. (2002). Informe Infraestrutura, Aviação Regional Brasileira - Modal Aéreo IV, BNDES. Rio de Janeiro, RJ, Brasil.

Caves, D. W., Christensen, L. R., \& Tretheway, M. W. (1984). Economies of density versus economies of scale: why trunk and local airline costs differ. Rand Journal of Economics, 15, 471-489.

Civil Aviation Authority - CAA. (2011). Airport market power assessments, Catchment area analysis Working Paper.

Das, A. K., Bardhan, A. K., \& Fageda, X. (2020). New regional aviation policy in India: Early indicators and lessons learnt. J. Air Transp. Manag., 88, 101870. https://doi.org/10.1016/j.jairtraman.2020.101870

Fageda, X., Suárez-Alemán, A., Serebrisky, T., \& Fioravanti, R. (2018). Air connectivity in remote regions: A comprehensive review of existing transport policies worldwide. J. Air Transp. Manag., 66, 65-75. https://doi.org/10.1016/j.jairtraman.2017.10.008

Falcão, V. A. (2013). Demanda aeroportuária de Manaus e sua influência para o setor de turismo da região. Journal of Transport Literature, Manaus, 7(1), 127-146. https://doi.org/10.1590/S2238-10312013000100008

Freire, L. L. A., \& Silva, A. R. (2017). Using Moran's I to plan potential regional aviation airports - The case of Brazil. Transportes, 26, 31-41. https://doi.org/10.14295/transportes.v26i1.1369

Hakim, M. M., \& Merkert, R. (2016). The causal relationship between air transport and economic growth: Empirical evidence from South Asia. Journal of Transport Geography, 56, 120-127. https://doi.org/10.1016/j.jtrangeo.2016.09.006

Hakim, M. M., \& Merkert, R. (2019). Econometric evidence on the determinants of air transport in South Asian countries, Transport Policy. https://doi.org/10.1016/j.tranpol. 2017.12.003

Hess, S. (2010). Theory and Practice in Modelling Air Travel Choice Behaviour. In: POSTORINO, M.N. (Org.). Development of Regional Airports: Theoretical Analyses and Case Studies. 1ed.: WIT Press, p. 109-126.

IBGE. (2016). Instituto Brasileiro de Geografia e Estatística - Estimativas de População. Retrieved May 12, 2017, from http://www.ibge.gov.br/home/estatistica/populacao/estimativa2015/estimativa_tcu.shtm

Karlaftis, M. G., Zografos, K., Papastavrou, J. D., \& Charnes, J. M. (1996). Methodological Framework for Air Travel Demand Forecasting. Journal of Transportation Engineering, 122(2), 96-104. https://doi.org/10.1061/(ASCE)0733-947X(1996)122:2(96)

Kopsch, F. (2012). A demand model for domestic air travel in Sweden. Journal of Air Transport Management, 20, 46-48.

Lieshout, R. (2012). Measuring the size of an airport's catchment area. Journal of Transport Geography, 25, 2734.

Marazzo, M., Scherre, R., \& Fernandes, E. (2010). Air transport demand and economic growth in Brazil: A time series analysis. Transportation Research Part E, 46, 261-269.

Merkert, R., \& Beck, M. J. (2020). Can a strategy of integrated air-bus services create a value proposition for regional aviation management? Transp. Res. Part A Policy Pract., 132, 527-539. 
https://doi.org/10.1016/j.tra.2019.12.013

Oliveira, A. V., \& Salgado, L. H. (2008). Constituição do marco regulatório para o mercado brasileiro de aviação regional. NECTAR/ABETAR. São José dos Campos. Retrieved September 22, 2017, from http://pantanalbraziltourism.com/fotos/arquivos/96.pdf

Paiva, I. C. P. L., \& Muller, C. (2014). Competição entre o ônibus e o avião no transporte interestadual de passageiros na Região Metropolitana de Belo Horizonte. Journal of Transport Literature, 8(1), 109-124.

Postorino, M. N. (2010). Air Demand Modelling: Overview and Application to a Developing Regional Airport. In: POSTORINO, M.N. (Org.). Development of Regional Airports: Theoretical Analyses and Case Studies. 1 ed.: WIT Press, p. 77-108.

Postorino, M. N. (2011). Environmental Effects of Airports Nodes: A Methodological Approach. In Postorino, M. N. (Ed.), Regional Airports (1st ed., pp. 117-129). WIT Press.

Postorino, M. N., \& Praticò, F. G. (2012). An application of the Multi-Criteria Decision-Making analysis to a regional multi-airport system. Res. Transp. Bus. Manag., 4, 44-52. https://doi.org/10.1016/j.rtbm.2012.06.015

Redondi, R., Malighetti, P., \& Paleari, S. (2013). European connectivity: The role played by small airports. $J$. Transp. Geogr., 29, 86-94. https://doi.org/10.1016/j.jtrangeo.2013.01.010

Rochel, J. J. B. (2000). Factores Determinantes de la Demanda de Transporte Aéreo y Modelos de Previsión. Boletin Economico de Revistas ICE - Información Comercial Española, n. 2652, p. 41-48.

Ruiz, M. R., Hecktheuer, L. M., \& Barros, G. G. B. (2014). Concentração e Rivalidade em Transporte Aéreo de Passageiros: Reflexões a Partir de Casos Recentes. In: SILVA, L. N. (Org.). Regulação e concorrência no setor aéreo no Brasil: alternativas possíveis. 1ed.: Singular, 2014, p. 201-230.

Sivrikaya, O., \& Tunç, E. (2013). Demand Forecasting for Domestic Air Transportation in Turkey. The Open Transportation Journal, (7), 20-26.

Tolcha, T. D., Brathen, S., \& Holmgren, J. (2020). Air transport demand and economic development in sub-Saharan Africa: Direction of causality. Journal of Transport Geography, 86(102771). https://doi.org/10.1016/j.jtrangeo.2020.102771

Tsekeris, T. (2009). Dynamic analysis of air travel demand in competitive island markets. Journal of Air Transport Management, 15, 267-273.

Turolla, F. A., Lima, M. F. F. L., \& Ohira, T. H. (2011). Políticas públicas para a melhora da competitividade da aviação regional brasileira. Revista de Literatura dos Transportes, 5(4), 188-231.

Valdes, V. (2015). Determinants of air travel demand in Middle Income Countries. Journal of Air Transport Management, 42, 75-84. https://dx.doi.org/10.1016/j.jairtraman.2014.09.002

Wadud, Z. (2015). Imperfect reversibility of air transport demand: Effects of air fare, fuel prices and price transmission. Transportation Research Part A, 72, 16-26. http://dx.doi.org/10.1016/j.tra.2014.11.005

Wu, H., Hong Tsui, K. W., Ngo, T., \& Lin, Y.-H. (2020). Impacts of aviation subsidies on regional wellbeing: Systematic review, meta-analysis and future research directions. Transp. Policy. https://doi.org/10.1016/j.tranpol.2020.08.003

\section{Copyrights}

Copyright for this article is retained by the author(s), with first publication rights granted to the journal.

This is an open-access article distributed under the terms and conditions of the Creative Commons Attribution license (http://creativecommons.org/licenses/by/4.0/). 